\title{
Milliliter Times Centimeter of Water
}

National Cancer Institute

\section{Source}

National Cancer Institute. Milliliter Times Centimeter of Water. NCI Thesaurus. Code C135521.

A unit of measure for volume change calculation expressed by multiplying the volume of air flow in $\mathrm{mL}$ by the air pressure in $\mathrm{cm} 2 \mathrm{O}$. 